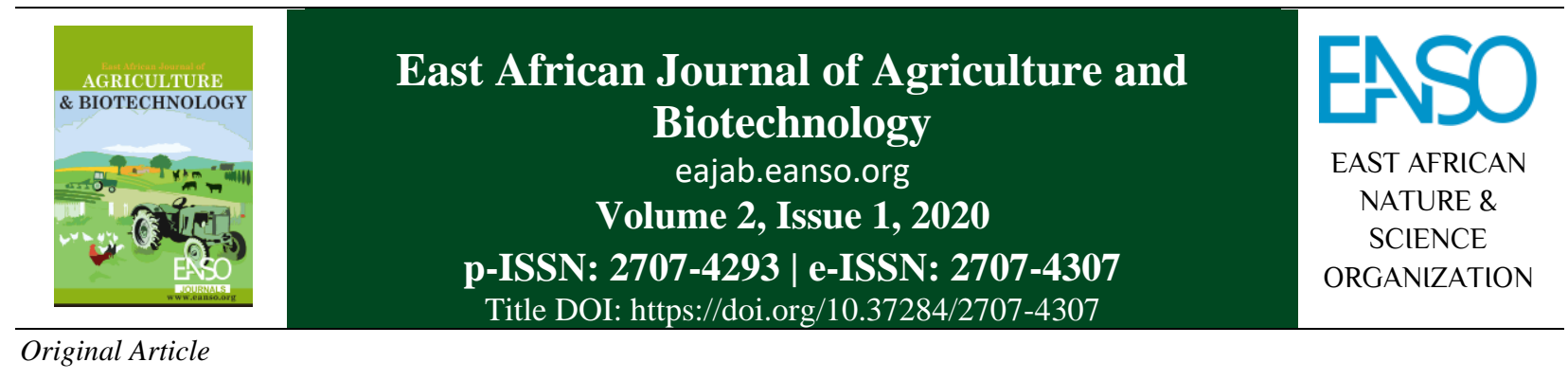

\title{
Socioeconomic Determinants of Adoption of Eco-Friendly Farming Practices in Agroecosystems of Embu County, Kenya
}

\author{
Moses Kathuri Njeru \\ Department of Environmental Studies \& Resources Development, Chuka University, P. O. Box 109-60400, Chuka, Kenya. \\ Email: mnkathuri@gmail.com
}

Article DOI: https://doi.org/10.37284/eajab.2.1.112

Article history:
Received: 15 Jan 2020
Accepted: 03 Feb 2020
Published: 07 Feb 2020
Keywords:
Adoption,
Eco-Friendly,
Farming Practices,
Socioeconomic Factors,
Households

Households

\begin{abstract}
A close relationship exists between the environment and agriculture. A change in either of them invariably affects the other. That is why environmentalists, the government and the non-governmental organisations have supported the development and adoption of Eco-friendly Farming Practices (EFFPs) by farming households. Earlier studies had indicated that adoption of EFFPs was low in some areas while other regions of Kenya and Embu County had successfully adopted these practices. However, even where there was a successful adoption of EFFPs, the type and number of EFFPs varied greatly. These inconsistencies in the type of EFFPs and the adoption of EFFPs necessitated this study. Therefore, this study carried out in Embu County sought to find out the influence of socioeconomic factors on the adoption of the EFFPs. Ex post facto research design was used in the study. Through multi-stage random sampling, 402 household heads were selected and all the 32 extension officers in the area were interviewed. Household head questionnaires, interview schedule and observation schedule were used for data collection. These research instruments were piloted, validated and their reliability established before data collection. Data was cleaned and entered into Statistical Package for Social Sciences (SPSS) version 22 for analysis. Frequencies, Chi-square and regression model were used for analysis. Average income from agriculture, gender, farming experience, level of education, size of the farm and age were statistically significant $(\mathrm{p}<0.05)$ in influencing the adoption of EFFPs among households of Embu County. The study concluded that the socioeconomic factors were significant in influencing the adoption of EFFPs among households of Embu County. This implies that the household socioeconomic characteristics must be considered in designing effective environmental programmes in the County.
\end{abstract}




\section{APA CITATION}

Njeru, M. (2020). Socioeconomic Determinants of Adoption of Eco-Friendly Farming Practices in Agroecosystems of Embu County, Kenya. East African Journal of Agriculture and Biotechnology, 2(1), 1-11. https://doi.org/10.37284/eajab.2.1.112

\section{CHICAGO CITATION}

Njeru, Moses. 2020. "Socioeconomic Determinants of Adoption of Eco-Friendly Farming Practices in Agroecosystems of Embu County, Kenya”. East African Journal of Agriculture and Biotechnology 2 (1), 1-11. https://doi.org/10.37284/eajab.2.1.112.

\section{HARVARD CITATION}

Njeru, M. (2020) "Socioeconomic Determinants of Adoption of Eco-Friendly Farming Practices in Agroecosystems of Embu County, Kenya”, East African Journal of Agriculture and Biotechnology, 2(1), pp. 1-11. doi: 10.37284/eajab.2.1.112.

\section{IEEE CITATION}

M. Njeru, "Socioeconomic Determinants of Adoption of Eco-Friendly Farming Practices in Agroecosystems of Embu County, Kenya", EAJAB, vol. 2, no. 1, pp. 1-11, Feb. 2020.

\section{MLA CITATION}

Njeru, M. "Socioeconomic Determinants of Adoption of Eco-Friendly Farming Practices in Agroecosystems of Embu County, Kenya". East African Journal of Agriculture and Biotechnology, Vol. 2, no. 1, Feb. 2020, pp. 1-11, doi:10.37284/eajab.2.1.112.

\section{INTRODUCTION}

The environment and its resources form the basis for the livelihood of human beings, sustenance of economies and agricultural development in the world (Mutuku et al., 2017). Use of environmental resources for agriculture is central in the global economy accounting for over $24 \%$ of the global Gross Domestic Product (Smith et al., 2007). One of the key roles of agriculture is food production. To meet the food requirements for the ever-growing human global population (expected to rise to 11 billion by 2100), modern agriculture or conventional agriculture has been practised for long. The conventional agriculture involves intensified mechanization, intensified use of pesticides and excess inorganic fertilizers, expansion of irrigated land, specialization and breeding of high yielding crops (Tal, 2018). Notably, conventional farming practices lead to a sudden increase in farm production. However, the increase in production is not sustainable. Additionally, the intensified conventional agriculture stretches environmental resources to limits thus weakening their natural processes (United Nations Environment Programme [UNEP], 2008). For instance, these conventional agricultural practices have been associated with acute soil degradation (Ngetich, et al., 2012), environmental pollution, soil acidification, biodiversity loss and salinization (Hurni, 2000; Rasul \& Thapa, 2004;
Roling, 2005). Moreover, agriculture has been directly affected by climate variability and change, agriculture is responsible for about $30 \%$ of the total greenhouse emissions (Theodor et al., 2014).

In Africa, farmers face environmental challenges of low crop yields, low profits, land degradation, soil acidification, soil loss and pollution (Du Preez et $a l ., 2011)$. Since agriculture is central to Africa's economy, the successful development of agriculture should take into consideration the sustainable use of environmental resources (Tal, 2018). To address the environmental challenges associated with agriculture and simultaneously provide agroecosystem services, environmentalists have supported a paradigm shift in farming practices by encouraging the adoption of EcoFriendly Farming Practices (EFFPs). EFFPs constitute a set of farming practices that sustainably support the provision of agroecosystem services and simultaneously mitigate environmental challenges associated with agriculture (Mozzato et al., 2018). These farming practices broadly consider tillage practices, cropping systems, choice of farm seeds, farms feeds, soil fertility practices, farm biodiversity, pests and diseases management, soil conservation, water conservation and marketing of the farm produce as well as crosscutting management practices. They are considered environmentally friendly because these practices are based on similar tenets (tripod dimensions of ecological, social and economic aspects) as 
environmental sustainability (Crosson, 1992; Shaller, 1993; Conway, 1994; Rossing et al., 1997; Berentsen et al., 1998; Cobb et al., 1999; Pretty \& Hine, 2001). Therefore, EFFPs in agroecosystems ensure that all practices geared towards food production or meeting such other market requirements are carried out without incurring significant negative environmental impacts (Sydorovych \& Wossink, 2008; Vandermeulen \& Van, 2008; Siwar et al., 2009; Mozzato et al., 2018).

EFFPs through their multi-dimensional approach have been associated with benefits such as increased farm production, increased biodiversity, sustained soil fertility, reduced soil erosion, increased soil moisture, reduced environmental pollution, improved food security and income stability to farming households (Gliessman, 1990; Altieri, 1999; Legg, 1999; Pacini et al., 2004; Peacock \& Sherman, 2010; Njeru, 2015). EFFPs support the livelihood and equity goals of resourcepoor farmers. In addition, EFFPs enhance social sustainability. With regard to ecological sustainability, problems of pest resistance and outbreaks resulting from large-scale monoculture production are reduced by smaller-scale multiple cropping, crop rotations (Magdoff, 1989), use of cover crops (Liebman, 1989) and mulching (Vambe, 1997). There is also increased agrobiodiversity, reduced leaching and run-off losses and wider environmental protection (Magdoff, 1989; Tal, 2018). EFFPs have been associated with high soil carbon sequestration (Mutegi et al., 2008). This sequestered carbon reduces the amount of carbon that would otherwise contribute to the greenhouse effect. This indicates the great potential of EFFPs in mitigating global warming. These social, economic and ecological benefits should make sustainable agriculture suitable for all farming households world over and especially in Africa where there are resource-poor smallholder farmers relying on agriculture for economic development.

To realise the benefits of EFFPs including overall environmental sustainability, farmers have to accept and adopt these practices. Success stories and benefits of EFFPs have been recorded in South Africa, Zimbabwe and Zambia (Yadate, 2007). Despite the environmental benefits associated with
EFFPs, their adoption rates in many African countries remain low (Giller, et al., 2009; International Assessment of Agricultural Knowledge, Science and Technology for Development [IAASTD], 2009).

Agriculture being the backbone of Kenya's economy and a great user of environmental resources, adoption of EFFPs should be prioritised. In Kenya, very low (0-6\%) adoption rates of EFFPs among farming households have been reported (Republic of Kenya, 2007; Njeru, 2015; Chomba, 2016). However, despite the low adoption in some regions, some households have been reported to have high adoption intensity of EFFPs (Olwande, Sikei \& Mathenge, 2009; Suri, 2011). Some EFFPs were long introduced in Embu County by the colonial government. The government (both county and national) and NGOs have been promoting the adoption of EFFPs among farming households in Embu County. The study, therefore, sought to examine the influence of socioeconomic factors on the adoption of EFFPs in Embu County. This is because appropriate and effective intervention measures would be better developed after examining the socioeconomic factors influencing adoption of EFFPs through which environmental conservation would be realised. The socioeconomic determinants and their influence were examined against the adoption of EFFPs covering soil fertility techniques, tillage practices, cropping systems, agroforestry, soil and water conservation practices.

\section{MATERIALS AND METHODS}

The study was carried out in Embu County in Eastern part of Kenya. Embu County borders Kirinyaga County to the West, Kitui County to the east, Tharaka Nithi County to the North and Machakos County to the South. The County is located between $37^{\circ} 3^{\prime}$ ' and $37^{\circ} 9$ ' east. Embu County rises from about $515 \mathrm{~m}$ above sea level at the Tana basin in the east to over $4870 \mathrm{~m}$ on top of Mt. Kenya in the North West. The human settlement in the county is mainly rural. The County's agroecology has influenced the settlement pattern. Embu County lies at an altitude of about 1,700 $\mathrm{m}$ above sea level, experiences a bimodal type of rainfall with long rains falling from March to June while the short rains start at around October to February (Jaetzold, et al., 2007). A great majority of the farmers are 
small scale holders whose major cropping enterprises are coffee, tea, maize, beans, potatoes, and macadamia. The households rear cattle, goats, sheep, poultry and bees (County Government of Embu, 2014). The combination and intensity of these enterprises vary across the upper midlands (UM1 and UM 2) and lower midlands (LM) of the County. According to the 2009 population and housing census, Embu County had 80,138 households (County Government of Embu, 2014).

Ex post facto research design was used to determine the influence of socioeconomic factors on the adoption of EFFPs among the farming households in Embu County. All the 80,138 farming households and the 32 agricultural extension officers in the Embu West, Embu East and Embu North sub-counties were targeted in the study. These extension officers represented the informed specialists, and the 80,138 farming household heads being the users of the EFFPs. The sample used in the study was selected through a multistage sampling technique. The first stage involved a purposive selection of the block of the three subcounties where EFFPs were intensively introduced. The three sub-counties share similar agroecological conditions. Twenty-four sub-locations (out of the 70 sub-locations) were randomly chosen and from these sub-locations, a sample size of 402 household heads was proportionately and randomly chosen for the study.

The sampling unit was the household head because of their influence on decisions regarding farming practices. The household questionnaires were administered on house to house basis. In cases where the household head was not present, a spouse was interviewed and if the spouse was absent any adult of the household was interviewed. Where none of these was present, the interview was postponed. Before the actual use of the questionnaire, it was pretested in a neighbouring county and its reliability established. An observation schedule which is relatively free of bias was also used to supplement information collected on various observable field practices.

Sixteen EFFPs that were relevant in the study area were considered in the study. These EFFPs considered specific attributes on cover cropping, weed management, cropping systems, soil fertility techniques, use of integrated pest management, minimum tillage, retaining plant residues/mulching, use of inorganic pesticides, soil testing, soil fertility techniques and agroforestry.

The socioeconomic attributes examined were gender of the household head, level of income from agriculture, highest education level attained by the household head, household's farm size holding, farming experience and age of the household head. The collected data was cleaned and analysed using the Statistical Package for Social Sciences (SPSS) version 22. The relationship between the adoption of EFFPs and selected socioeconomic factors were determined by the use of chi-square statistics at a $5 \%$ significance level. The computed $\mathrm{p}$-value is compared with 0.05 at $5 \%$ significance level. If the p-value would be less than 0.05 , then, there would be a significant relationship between the adoption of EFFPs and the socioeconomic attributes. If the p-value would be more than 0.05 , then the study would conclude that a statistically significant relationship did not exist.

\section{RESULTS AND DISCUSSIONS}

\section{Influence of Socioeconomic Factors on the Adoption of EFFPs}

The socioeconomic factors that were found to be statistically significant in influencing adoption of EFFPS were: gender of the respondents, age, farming experience, size of the farm, main farming purpose, respondents' primary activity, the highest level of education attained and annual income from agriculture (Table 1). 
East African Journal of Agriculture and Biotechnology, Volume 2, Issue 1, 2020

Article DOI: https://doi.org/10.37284/eajab.2.1.112

Table 1: Regression Coefficients for Socio-economic Factors influence on Adoption of Eco-Friendly Farming Practices

\begin{tabular}{lllll}
\hline Independent Variables & B & Std. Error & t & p-value \\
\hline Constant & 2.886 & 0.154 & 18.717 & 0.0001 \\
Gender of Respondent & 0.059 & 0.022 & 2.619 & 0.009 \\
Age of Respondents & -0.109 & 0.025 & -4.437 & 0.0001 \\
Farming Experience & 0.136 & 0.021 & -6.575 & 0.0001 \\
Size of Farm & 0.070 & 0.023 & -3.008 & 0.003 \\
Main Farming Purpose & 0.351 & 0.049 & 7.177 & 0.0001 \\
Highest Level of Education Attained & 0.214 & 0.016 & -13.349 & 0.0001 \\
Respondent's Primary Activity & -0.196 & 0.026 & -7.415 & 0.0001 \\
Annual income from Agriculture & 0.092 & 0.014 & 6.430 & 0.0001 \\
\hline
\end{tabular}

The equation for the model is represented by:

$\mathrm{Y}=\beta_{0}+\beta_{1} \mathrm{x}_{1}+\beta_{2} \mathrm{X}_{2}+\beta_{3} \mathrm{X}_{3}+\beta_{4} \mathrm{X}_{4}+\beta_{5} \mathrm{X}_{5}+\beta_{6} \mathrm{X}_{6}+\beta_{7} \mathrm{X}_{7}$ $+\beta_{8} \mathrm{x}_{8}+\mathrm{e}$

Where $\mathrm{Y}=$ Adoption status, $\beta_{0}=$ intercept, $\beta_{1} \mathrm{x}_{1} \ldots \ldots$ $\beta_{8} \mathrm{X}_{8}=$ coefficients of the independent variables and $\mathrm{e}=$ random error term. Therefore, Adoption $=2.886$ +0.059 (Gender) + -0.109 (Age) + 0.136 (Farming experience $)+0.070$ (Size of the farm $)+0.351$ (Main farming purpose) +0.214 (Highest level of education) +0.196 (Respondent's Primary Activity) + 0.092 (Annual income from agriculture).

\section{Gender of the Respondents}

The regression model shows that one unit of change in the adoption of EFFPs can be explained by 0.059 of gender if the other factors were held constant. A chi-square test on the relationship between gender of the respondents and the adoption of EFFPs yielded a p-value of 0.005 which is less than 0.05 . This implied a significant relationship between the gender and adoption of EFFPs (Table 1). Women were more likely to adopt EFFPs than men. This observation is in tandem with the findings of (Njeru, 2015). However, this finding contradicts the observations by Akama et al., (1995), Fiallo and Jacobson (1995), De Boer and Baquete (1998) and Infield (1998); who believed that gender had no influence towards the adoption of environmental conservation practices.

\section{Level of Income from Agriculture}

Less than $1 \%$ of the respondents earned either Kshs. 20,000 or less from agriculture, while $2.7 \%$ earned between Kshs. 21,000 and Kshs 40,000; $11.7 \%$ earned Kshs. 41,000-60,000 while more than half (57\%) of the respondents earned above Kshs 80,000 in a year (Table 2).

Table 2: Household's Annual Income from Agricultural Activities

\begin{tabular}{lll}
\hline $\begin{array}{l}\text { Range of incomeFrequency } \\
\text { (Kshs) }\end{array}$ & Percent \\
\hline $1-20,000$ & 2 & 0.5 \\
$21,000-40,000$ & 11 & 2.7 \\
$41,000-60,000$ & 47 & 11.7 \\
$61,000-80,000$ & 113 & 28.1 \\
Over 80,000 & 229 & 57.0 \\
Total & $\mathbf{4 0 2}$ & $\mathbf{1 0 0 . 0}$ \\
\hline
\end{tabular}

Regression analysis showed that a unit change in the adoption of EFFPs can be explained by 0.092 unit change in household income levels from agriculture (Table 1). The obtained p-value of 0.0001 was less than 0.05 ; therefore, the study found that there was a statistically significant and positive relationship between households' levels of 
income from agriculture and adoption of EFFPs. This implies that those who earned more from agriculture adopted more of EFFPs while those who earned little from agricultural activities adopted less of the EFFPs. This positive relationship between farm income and adoption of EFFPs is in agreement with the findings of Shields, Rayuniyar and Goode (1993) who averred that high-income levels positively influence the adoption of technologies while low farm income inhibits adoption of EFFPs. Higher levels of income from whichever source to the farm widen the financial base of a farmer and this hastens the adoption of technologies. However, the study's finding on the positive influence of income on adoption contradicts the opinion of Mengstie (2009). Mengstie holds that income levels do not influence the adoption of EFFPs.

Where households realised more income from agriculture, then there was a high likelihood that they ploughed back part of the income into improving the agricultural enterprises. This included adopting more EFFPs because they support the production that gives higher income. With higher levels of income from agriculture, putting up structures like gabions, terraces (for soil and water conservation measures), engaging hired labour for the more labour-engaging EFFPS (composting and mulching) is made easier if households have more income. The households can even buy compost manure from fellow farmers. Lower-income levels mean that more competing needs will be addressed before addressing farmrelated expenses. This low income is bound to be lower in the next season because fewer inputs (investment) went into the EFFPs. This lack of investment in EFFPs leads to low production and then less income. That sets in motion the cycle of less investment and low production and subsequently low income.

\section{Educational Level of the Household Head}

Slightly more than half (54\%) of respondents had a minimum of secondary level of education, a third $(33.8 \%)$ had attained up to the primary level of education while $11.9 \%$ had no formal education (Table 3).
Table 3: Highest Educational Level Attained by the Household Head

\begin{tabular}{lll}
\hline Educational Level & Frequency & Percent \\
\hline Post-secondary & 84 & 20.9 \\
Secondary & 134 & 33.3 \\
Primary & 136 & 33.8 \\
No formal education & 48 & 11.9 \\
Total & $\mathbf{4 0 2}$ & $\mathbf{1 0 0 . 0}$ \\
\hline
\end{tabular}

Regression analysis showed that a unit change in the adoption of EFFPs could be explained by 0.214 unit change in the level of education of the household head if the other factors were held constant. A statistically significant positive relationship existed between the adoption of between the highest level of formal education attained by the household and the adoption of EFFPs (Table 1). This finding is consistent with observations by Asrat et al., (2004), Tenge et al., (2004), Bodnár et al., (2006), and Anley et al., (2007) who associated higher level of education with higher adoption rates. This positive relationship can be attributed to the fact that higher education levels do infer a greater capacity for adopters to learn and decide about new technologies. This implies that environmental education and higher conservation efforts would be successful among highly educated people because they are more open to new ideas. Higher education levels also increase farmers' creative and innovative capacity. With higher levels of education, a farmer is expected to appreciate and understand the influences and relationship between environment and agricultural practices and thereof adopt more of the EFFPs.

The findings, however contrast, earlier observations by other studies (Tesfaye, 2003; Rahmeto, 2007; Tigist, 2010). In his study on soil and water conservation measures in Konso Wolaita and Wello areas of Ethiopia; Tesfaye (2003) observed that no significant relationship existed between higher adoption rates of soil and water conservation measures and higher education levels. This study acknowledges the importance of formal education in enhancing environmental conservation. The higher the advancement in education level, the higher the likelihood that they are exposed to the intricate interactions of the environment and agriculture. Some of the 
household heads could have been trained in agriculture or even related disciplines.

\section{Household's Farm Size}

Four-fifths of the respondents had their farm's sizes ranging between one to five acres, $12.4 \%$ of the households had land sizes between six to ten acres while $7.5 \%$ of the respondents owned over 10 acres of land (Table 4). Essentially the majority of the households in the study area are smallholder farmers.

\section{Table 4: Farm Size Holdings by Households}

\begin{tabular}{lll}
\hline Farm Size (Acres) & Frequency & Percent \\
\hline $1-5$ & 322 & 80.1 \\
$6-10$ & 50 & 12.4 \\
Over 10 & 30 & 7.5 \\
Total & $\mathbf{4 0 2}$ & $\mathbf{1 0 0 . 0}$ \\
\hline
\end{tabular}

Regression analysis revealed a positive statistically significant relationship between adoption of EFFPs and the size of the farm (Table 1). The analysis further showed that a unit change in the adoption of EFFPs could be explained by 0.07 unit change in the size of the farm. These results indicated a tendency of households on relatively bigger farm sizes to adopt more EFFPs than households on smaller farm sizes. These findings are consistent with earlier observations by Kasenge (1998), Uaiene et al., (2009) and Mignouna et al, (2011). Melesse (2018) to avers that the adoption of new agricultural technologies correlates positively with land size. Those in support of the positive relationship between farm size and adoption advance two reasons: first, return on investment is faster and stable in larger farm sizes. Second, is that larger farm sizes have the advantage of more land to carry out more trials (Carlisle, 2016).

Other scholars, however, have differed with the positive relationship between farm size and adoption of agricultural technologies. Carlisle (2016) argues that smallholder farmers can identify a problem of soil degradation faster than large holder farmers, therefore smallholder farmers adopt more than farmers with large sizes of land. Other studies established that no relationship exists between the adoption of technology and farm size (Bonabana-Wabbi, 2002; Samiee, et al., 2009; Chomba, 2016).

\section{Age of the Household Heads}

About half $(51 \%)$ of the respondents were aged between 41-50 years. Forty per cent of the respondents were over 50 years of age while the youthful and energetic segment (31-40 years) constituted a paltry $8 \%$ of the respondents. A negligible $1 \%$ of the respondents were the youngest aged between 20-30 years (Figure 1). These were the youthful farmers who had ventured into farming.

\section{Figure 1: Age of the Household Heads}

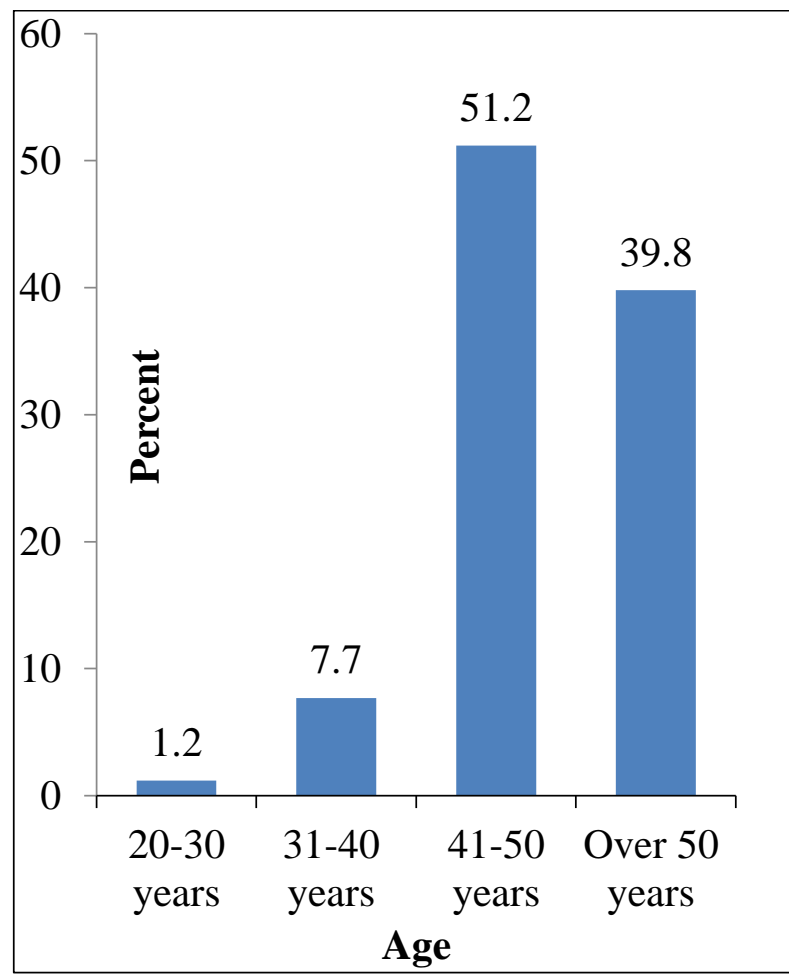

The age of the household heads was examined against the adoption status of EFFPs (adopted once, adopted more than once and those who have never). The greatest proportion of the adopters as found among household heads aged between 41-50 years. The least of the adopters were aged over 50 years (Table 5). 
East African Journal of Agriculture and Biotechnology, Volume 2, Issue 1, 2020

Article DOI: https://doi.org/10.37284/eajab.2.1.112

Table 5: Adoption Status of Eco-Friendly Farming Practices by Age

\begin{tabular}{lllll}
\hline Age of the Respondents & $\mathbf{N}$ & \multicolumn{2}{l}{ Status of adoption (\%) } & \\
& & Never & Adopted once & More than once \\
\hline 20-30 Years & 5 & $0(0)$ & $1(20 \%)$ & $4(80 \%)$ \\
31- 40 Years & 31 & $0(0)$ & $4(13.0 \%)$ & $27(87.0 \%)$ \\
41-50 Years & 206 & $0(0)$ & $18(8.7 \%)$ & $188(91.3 \%)$ \\
Over 50 Years & 160 & $7(4.4 \%)$ & $94(58.8 \%)$ & $59(36.9 \%)$ \\
Total & 402 & 7 & & \\
\hline
\end{tabular}

Regression analysis showed that if all factors were held constant, a unit change in the adoption of EFFPs could be explained by 0.109 unit change in the age of the farmer (Table 1). Further, a statistically significant but negative relationship existed between the age of the household head and adoption of EFFPs in Embu County. This corroborates observations by Mishra et al., (2018) who found out that the age of the farmer had a significant, but negative, effect on conservation practices. However, the findings contrast the findings by Tigist (2010) who found a positive relationship between age of the farmer and adoption of conservation practices. The study avers that more adoption of EFFPs is likely to be found among younger and energetic household heads while the elderly were not likely to adopt more EFFPs. The younger household heads (also likely to be educated) were more receptive to new technologies hence their higher adoption of EFFPs.

\section{Farming Experience of the Household Head}

A fifth $(20.6 \%)$ of the respondents had a farming experience spanning between one to 10 years; slightly more than half $(51.7 \%)$ of the respondents had 11-20 years of farming experience. More than a quarter $(27.6 \%)$ had over 20 years of farming experience (Table 6). Therefore, more than three quarters $(79.3 \%)$ of the households had over ten years in farming. This is substantially a long period of time for a household to have learnt and evaluated new technologies. Farming experience is a household characteristic representing the time spent in undertaking farming activities. The household heads over time can evaluate the success and failure in crop production.
Table 6: Farming Experience of the Household Head

\begin{tabular}{lll}
\hline $\begin{array}{l}\text { Farming experience } \\
\text { (Years) }\end{array}$ & Frequency & Percent \\
\hline $1-10$ & 83 & 20.6 \\
$11-20$ & 208 & 51.7 \\
Over 20 & 111 & 27.6 \\
Total & $\mathbf{4 0 2}$ & $\mathbf{1 0 0 . 0}$ \\
\hline
\end{tabular}

A unit change in the adoption of EFFPs could be explained .136 unit change in the farming experience of the farmer if all the other factors were held constant (Table 1). The regression analysis further showed a statistically significant and a positive relationship between adoption rates and farming experience This agrees with what Kidane (2001), Melaku (2005) and Yishak (2005) had earlier observed that households with longer farming experience had accumulated knowledge and skills in farming which enabled them to adopt EFFPs faster. Similarly, Mahdi (2005) observed a statistically significant mean difference in the farming experience between adopters and nonadopters of improved sorghum varieties in Ethiopia.

The study found out that the more experienced households adopted more EFFPs than households with fewer years of farming experience. The length of time a household is involved in farming activities serves as a learning forum. The more experienced households over time can evaluate the success and failures of technologies and practices. This made the more experienced households to adopt more. For example, a household that has long adopted composting, in realising the high yields might be willing to adopt other EFFPs. 


\section{CONCLUSION AND RECOMMENDATION}

The gender of the farmer, farming experience, level of education, size of the farm, average income earned from agriculture, and ownership status of the farm had statistically significant relationship with adoption of the EFFPs while age of the farmer and their primary activity did not have a significant influence on the adoption of the EFFPs among households Embu County, Kenya. In designing effective environmental education for conservation programmes, the socio-economic attributes of the targeted population must be evaluated and examined.

\section{REFERENCES}

Akama, J., Lant, C. \& Burnet, D. (1995). Conflicting Attitudes towards Wildlife Conservation Programme in Kenya. Society and Natural Resources 8, 133-144.

Anley, Y., Bogale, A., \& Haile-Gabriel, A. (2007). Adoption decision and use intensity of soil and water conservation measures by smallholder subsistence farmers in Dedo district, western Ethiopia. Land Degradation \& Development, 18(3), 289-302.

Asrat, P., Belay, K., \& Hamito, D. (2004). Determinants of farmers' willingness to pay for soil conservation practices in the southeastern highlands of Ethiopia. Land Degradation \& Development, 15(4), 423-438.

Bodnár, F., Schrader, T., \& Van Campen, W. (2006). How Project Approach Influences Adoption of Soil and Water Conservation by Farmers; Examples from Southern Mali. Land Degradation and Development, 17, 479-494.

Bonabana-Wabbi, J. (2002). Assessing Factors Affecting Adoption of Agricultural Technologies: The Case of Integrated Pest Management (IPM) in Kumi District. Unpublished Thesis, Uganda

Carlisle, L. (2016). Factors influencing farmer adoption of soil health practices in the United States: A narrative review. Agroecology and Sustainable Food Systems, 40(6), 583-613.
Chomba, T. M. (2016). Influence of Farmer's Characteristics, Agricultural Extension and Technology Specific Factors on Adoption of Organic Farming Technologies in Embu West Sub County, Embu, Kenya. (Unpublished Masters Project Report). University of Nairobi, Kenya.

County Government of Embu. (2014). Embu County Integrated Development Plan, 20132018. County Government of Embu.

De Boer, W. \& Baquete, D. (1998). Natural Resource Use, Crop Damage and Attitudes of Rural People in the Vicinity of the Maputo Elephant Reserve, Mozambique. Environmental Conservation, 5 (3): 208-218

Fiallo, E. \& Jacobson, S. (1995). Local Communities and Protected Areas: Attitudes of Rural Residents towards Conservation and Machililla National Park, Ecuador. Environmental Conservation, 26 (3): 241-249.

Gabre-Madhin, Z. \& Haggblade, S. (2001). Success in African Agriculture: Results of an Expert Survey. Washington, DC: International Food Policy Research Institute.

Giller, K. E, Witter, E., Corbeels, M. \& Tittonel, P. (2009). Conservation Agriculture and Smallholder Farming in Africa: The Heretics view. Field Crops Research, 114(1), 23-34.

Hurni, H. (2000). Soil Conservation Policies and Sustainable Land Management: A global overview. In: Napier, T. Napier, S.M., Tvrdon, J. (eds), Soil and Water Conservation Policies and Programmes: Successes and Failures. Boca Raton, Florida: CRC Press.

International Assessment of Agricultural Knowledge, Science and Technology for Development (2009). Executive Summary of the Synthesis Report. Washington, DC: International Assessment of Agricultural Knowledge, Science and Technology for Development.

Infield, M. (1998). Attitudes of Rural Communities towards Conservation and a Local 
Conservation area in Natal, South Africa. Biological Conservation, 45: 211-46.

Jaetzold, R., Schmidt, H., Hornet, Z. B., \& Shisanya, C. A. (2007). Farm Management Handbook of Kenya. Natural Conditions and Farm Information. 2nd Edition. Eastern Province. Ministry of Agriculture/GTZ, Nairobi, Kenya.

Kasenge, V. (1998). Socio-economic Factors Influencing the Level of Soil Management Practices on Fragile Land. In Proceedings of the 16th Conference of Soil Science Society of East Africa (Eds; Shayo Ngowi, A. J., Ley, G. and Rwehumbiza, F. B. R.), 13th-19th, December 1998, Tanga, Tanzania.

Kidane, G. (2001). Factors Influencing the Adoption of New Wheat and Maize Varieties in Tigray, Ethiopia: The case of Hawzien Woreda. (Unpublished M.Sc. Thesis). Haramaya University.

Mahdi, E. (2005). Farmers' Evaluation, Adoption and Sustainable Use of Improved Sorghum Varieties in Jijiga Woreda, Ethiopia. (Unpublished M.Sc Thesis). Haramaya University, Ethiopia

Melaku, G. (2005). Adoption and profitability of Kenyan top bar hive beekeeping technology. Study in Ambasal district of Ethiopia. (Unpublished M.Sc. Thesis). Haramaya University. Ethiopia

Melesse, B. (2018). A review on factors affecting adoption of agricultural new technologies in Ethiopia. Journal of Agricultural Science and Food Research, 9(3), 1-4.

Mengstie, F. A, (2009). Assessment of Adoption Behavior of Soil and Water Conservation Practices in the Koga Watershed, Highlands of Ethiopia: Thesis. Cornell University. Ethiopia.

Mignouna, B., Manyong, M., Rusike, J., Mutabazi, S., \& Senkondo, M. (2011). Determinants of Adopting Imazapyr-Resistant Maize Technology and its Impact on Household Income in Western Kenya. AgBioforum, 14(3), 158-163.
Mishra, B., Gyawali, B. R., Paudel, K. P., Poudyal, N. C., Simon, M. F., Dasgupta, S., \& Antonious, G. (2018). Adoption of sustainable agriculture practices among farmers in Kentucky, USA. Environmental Management, 62(6), 1060-1072.

Mutuku, M. M., Nguluu, S.N., Akuja, T., Lutta, M. \& Benard, P (2017). Factors that Influence the Adoption of Integrated Soil Fertility and Water Management Practices by Smallholder Farmers in the Semi-Arid Areas of Eastern Kenya. Tropical and Subtropical Agroecosystems, 20 (2017): $141-153$.

Ngetich, F. K., Shisanya, C. A., Mugwe, J. N., Mucheru-Muna, M. \& Mugendi, D. N. (2012). The potential of organic and inorganic nutrient sources in Sub-Saharan African crop farming systems, soil fertility improvement and integrated nutrient management: A global perspective. In Whalen, J, K. (Eds), Soil Fertility Improvement and Integrated Nutrient Management: A Global (p. 135-182). Rijeka, Croatia: InTech.

Njeru, M. K. (2015). Challenges and benefits of organic farming among farmers in Nembure Division, Embu County-Kenya. International Journal of Humanities and Social sciences, 5, 12.

Olwande, J., Sikei, G., \& Mathenge, M. (2009). Agricultural Technology Adoption: A Panel Analysis of Smallholder Farmers' Fertilizer use in Kenya. CEGA. Working Paper Series No. AfD-0908. Centre of Evaluation for Global Action. University of California, Berkeley.

Rahmeto, N. (2007). Determinants of Adoption of Improved Haricot Bean Production Package in Alaba Special Woreda, Southern Ethiopia. (Unpublished M.Sc Thesis) Haramaya University, Ethiopia

Rasul, G. \& Thapa, G. B. (2004). Sustainability of Ecological and Conventional Agricultural Systems in Bangladesh: An Assessment based on environment, economic and social perspectives. Agricultural Systems, 79, 327351 
Republic of Kenya. (2007). Environment, Water, and Irrigation Sector Report. Republic of Kenya.

Roling, N. (2005). Gateway to the Global Garden: Beta/Gamma Science for Dealing with Ecological Rationality. In: Pretty, J. (eds), The Earth Scan Reader in Sustainable agriculture. Earth Scan, London.

Samiee, A., Rezvanfar, A., Faham, E. (2009). Factors Affecting Adoption of Integrated Pest Management by Wheat Growers in Varamin County, Iran. African Journal of Agricultural Research, 4(5), 491-497.

Shields, M. L., Ganesh P. R., \& Goode, F. M. (1993). A Longitudinal Analysis of Factors Influencing Increased Technology Adoption in Swaziland, 1985-1991. The Journal of Developing Areas, 27 (July), 469-484.

Smith, P., Martino, D., Cai, Z., Gwary, D., Janzen, H., Kumar, P., McCarl, B., Ogle, S., O’Mara, F., Rice, C., Scholes, B., Sirotenko, O., Howden, M., McAllister, T., Pan, G., Romanennkov, V., Schneider, U. \& Towprayoon, S. (2007). Policy and Technological Constraints to Implementation of Greenhouse Gas Mitigation Options in Agriculture. Agricultural Economics \& Environment, 118: 6-28

Suri, T. (2011). Selection and Comparative Advantage in Technology Adoption. Econometrica 79(1): 159-209.

Tenge, A.J, De Graaff, J. \& Hella, J. P. (2004). Social and economic factors affecting the adoption of soil and water conservation in West Usambara Highlands, Tanzania. Land Degrad Dev 15: 99-114

Tesfaye, B. (2003). Understanding Farmers: Explaining Soil and Water conservation in Konso, Wolaita and Wello, Ethiopia. PhD Thesis, Wageningen University and Research Centre. Ethiopia

Theodor, F., Josef, K. \& Amir K. (2014). Conservation Agriculture in Developing Countries: The Role of Mechanization 1. Food and Agricultural Organizations of the United Nations.

Tigist, P. (2010). Adoption of Conservation Tillage Technologies in Metema Woreda, North Gondar Zone, Ethiopia. (Unpublished M.Sc Thesis). Haramaya University, Ethiopia.

Uaiene, R., Arndt, C., Masters, W. (2009). Determinants of Agricultural Technology Adoption in Mozambique. Discussion papers No. 67

United Nations Environmental Programme. (2008). Agriculture: The need for change-press releases in April 2008. In UNEP-United Nations Environmental Programme Washington/London/Nairobi/Delhi, 2008 Available from http://www.unep.org/Documents.Multilingual/ Default.asp?DocumentID=531\& Article $\mathrm{ID}=5769 \& \mathrm{l}=\mathrm{en}$

Yadate, D. M. (2007). Evaluating Agricultural Sustainability and Adoption/ Diffusion of Conservation Tillage in Sub-Sahara Africal (Ethiopia in some selected potential areas). Retrieved from http://www.sustainability.k.utokyo.ac.jp/members/documents/13-

Yadete.pdf

Yishak, G. (2005). Determinants of Adoption of Improved Maize Technology in Damot Woreda, wolaita Zone, Ethiopia. (Unpublished M.Sc Thesis). Alemaya University of Agriculture, Ethiopia 